\title{
Tumour necrosis factor receptor gene expression and shedding in human whole lung tissue and pulmonary epithelium
}

\author{
H. Nakamura, T. Hino, S. Kato, Y. Shibata, H. Takahashi, H. Tomoike
}

Tumour necrosis factor receptor gene expression and shedding in human whole lung tissue and pulmonary epithelium. H. Nakamura, T. Hino, S. Kato, Y. Shibata, H. Takahashi, H. Tomoike. (C) ERS Journals Ltd 1996.

ABSTRACT: This study aimed to investigate the expression of tumour necrosis factor receptor (TNF-R) at the gene and surface level, and its shedding in human lung tissue and a pulmonary epithelial cell line, A549.

Levels of gene expression of TNF-R were evaluated by Northern blot analysis. Human lung tissue expressed both type I and type II TNF-R gene, while A549 cells expressed only type I TNF-R gene. Phorbol ester upregulated and TNF- $\alpha$ downregulated the TNF-R gene expression in A549 cells. Consistent with these modulations of TNF-R gene expression, 125 I-TNF binding capacities were increased with phorbol ester stimulation and decreased with TNF stimulation after $24 \mathrm{~h}$ in A549 cells. The shedding of TNF-R from A549 cells was investigated using enzyme-linked immunosorbent assay (ELISA) for soluble type I TNF-R. Not only lung tissues but also A549 cells spontaneously released soluble type I TNF-R into the culture medium. Both phorbol ester and TNF stimulation accelerated the shedding of soluble TNF-R from A549 cells.

These results suggest that type I TNF-R gene expression and shedding of soluble TNF-R are differentially regulated in A549 cells. We conclude that tumour necrosis factor receptor surface expression is regulated, at least in part, at the gene expression level and shedding of soluble tumour necrosis factor receptor is modulated by inflammatory mediators, such as tumour necrosis factor in A549 cells.

Eur Respir J., 1996, 9, 1643-1647.
The First Department of Internal Medicine, Yamagata University School of Medicine, Yamagata, Japan.

Correspondence: H. Nakamura

The First Department of Internal Medicine Yamagata University School of Medicine Yamagata 990-23 Japan

Keywords: A549 cell line gene expression lung tissue

tumour necrosis factor receptor soluble tumour necrosis factor receptor

Received: July 291995

Accepted after revision March 311996

This study was supported in parts by grantsin-aid for Scientific Research (No. 05557038 , 06274202 and 06454284) from Ministry of Education, Science and Culture, Japan.
Tumour necrosis factor (TNF) is one of the most important cytokines, and plays a key role in inflammation, septic shock, cachexia, and tumour necrosis $[1,2]$. TNF is also involved in the pathogenesis of a variety of lung injuries and inflammation [3-6]. With regard to TNF receptors (TNF-Rs), two types of gene have been cloned and their transmembrane structures have been determined [7-14]. Type I TNF-R is a $55 \mathrm{kDa}$ receptor and is expressed mainly in cells of epithelial origin. Type II receptor is a $75 \mathrm{kDa}$ receptor and is predominantly expressed in cells of haematopoietic origin [10-14]. Both receptors bind TNF- $\alpha$ and TNF- $\beta$ with similar affinity [9], but they are independently regulated [15-17]. Their extracellular domains show 53\% homology; however, intracellular domains show no homology, suggesting differences in their signal transduction pathways [10-14]. Importantly, extracellular domains are shed from both receptors; soluble TNF-Rs bind to and inhibit the functions of TNF [7-14]. Although TNF plays a critical role in a variety of lung diseases and also lung host defence [1-6], few studies on TNF-Rs in the lung, particulary the pulmonary epithelium have been reported. In the present study, we investigated TNF-Rs both at levels of gene expression and surface expression, and the shedding of soluble
TNF-R using a pulmonary epithelial cell line, A549, as a model for pulmonary epithelial cells.

\section{Materials and methods}

\section{Cell and tissue cultures}

A549, a human pulmonary epithelial cell line (American Type Tissue Collection, Rockville, MD, USA; CCL185) was cultured in RPMI 1640 medium with $2 \mathrm{mM}$ glutamine, $10 \mathrm{U} \cdot \mathrm{mL}^{-1}$ penicillin, $10 \mathrm{\mu g} \cdot \mathrm{mL}^{-1}$ streptomycin, and $10 \%$ foetal bovine serum. In the majority of experiments, unless otherwise indicated, $24 \mathrm{~h}$ after incubation with serum-free RPMI 1640 medium, A549 cells were incubated alone or with either recombinant human TNF (10 $\mathrm{ng} \cdot \mathrm{mL}^{-1}$; Genzyme Corp., Boston, MA, USA) or phorbol myristate acetate (PMA) (80 nM; Sigma Chemical Co., St. Louis, MO, USA) for 3, 6 and $20 \mathrm{~h}$.

Normal lung tissues were obtained at surgery from patients with lung cancer. Subpleural, noninflamed bronchioloalveolar tissue far from lung cancer tissues was selected as a normal lung tissue. Freshly resected lung 
tissues along with lung cancer tissues were immediately sliced into 1-2 $\mathrm{mm}$ cubes and rinsed three times with phosphate-buffered saline (PBS).

\section{Probe preparation}

The probe for the type I TNF-R was a 304 base pair (bp) complementary deoxyribonucleic acid (cDNA) segment, including the sequence from the HindIII site to the EcoRI site of the TNF-RI cDNA [10-13], and that for type II TNF-R cDNA was a 930 bp segment [14]. Each was constructed using polymerase chain reaction amplification of ribonucleic acid (RNA) (after conversion to cDNA) from U937 cells (American Type Culture Collection; CCL 1593) with Taq polymerase (Perkin-Elmer Cetus Instruments, Norwalk, CT, USA) and primers specific for human type I TNF-R cDNA (TNFRI-S, 5'AAACCCAAGCTTCAGTCCCACTC-3'; and TNFRI-AS, 5'-TAGGCGCCGCACGAATTCCTTCCAGCGC-3'), and for human type II TNF-R cDNA (TNFRII-S, 5'-ATGTCTCGAGACCAGGAACTGAAACATC-3'; and TNFRII-AS, 5'-ATTCAAGCTTTAACTGGGCTTCATCCCAGC-3'). Both were cloned into pBluescript II SK+ (Stratagene, La Jolla, CA, USA) and both sequences were confirmed by the dideoxy chain-termination method [18]. The cDNA clone $\mathrm{pHF} \beta \mathrm{A}-1$ was used for the $\beta$-actin probe [19].

\section{Northern blot analysis}

Total cellular RNA was isolated by the acid guanidinium thiocyanate-phenol-chloroform method [20]. RNA $(12 \mu \mathrm{g})$ was electrophoresed in $1.2 \%$ agarose gel containing $3 \mathrm{M}$ formaldehyde in 3-(N-morpholino) propane sulphonic acid (MOPS) buffer [21, 22] and transferred to a nylon membrane (Nytran; Schleicher and Shcuell Inc., Keene, NH, USA). Membranes were prehybridized with hybridization buffer containing $0.5 \mathrm{M}$ sodium phosphate buffer, $1 \mathrm{mM}$ ethylenediamine tetra-acetic acid (EDTA), $0.5 \%$ bovine serum albumin (BSA) and $7 \%$ sodium dodecyl sulphate (SDS) at $65^{\circ} \mathrm{C}$ for $6 \mathrm{~h}$. Hybridization was performed at $65^{\circ} \mathrm{C}$ for $36 \mathrm{~h}$ with a ${ }^{32} \mathrm{P}$-labelled TNF-Rs or $\beta$-actin cDNA probe generated by the random priming method [23]. Membranes were washed sequentially at $25^{\circ} \mathrm{C}$ in $2 \times$ standard sodium citrate (SSC) $/ 0.1 \%$ $\mathrm{SDS}, 0.5 \times \mathrm{SSC} / 0.1 \% \mathrm{SDS}$ and finally at $65^{\circ} \mathrm{C}$ in $0.1 \times$ $\mathrm{SSC} / 0.1 \%$ SDS. Blots were then exposed to film (XAR-5; Eastman Kodak Co., Rochester, NY, USA) with intensifying screen (Eastman Kodak Co.).

\section{Quantitation of receptor level}

To confirm the binding of ${ }^{125}$ I-TNF proteins (46.6 $\mu \mathrm{Ci} \cdot \mu^{-1}{ }^{-1}$; Du Pont Co., Wilmington, DE, USA) to A549 cells, the cells were seeded in culture medium into a 15 $\mathrm{mm}$ tissue culture plate (Sumilon, Tokyo, Japan) at a density of $2.5 \times 10^{5}$ cells plate $^{-1}$. After a $24 \mathrm{~h}$ incubation at $37^{\circ} \mathrm{C}$ in the absence or the presence of TNF $(10$ $\left.\mathrm{ng} \cdot \mathrm{mL}^{-1}\right)$ or PMA $(80 \mathrm{nM})$, the plates were transferred to ice, the growth medium was removed, and $125 \mathrm{I}-\mathrm{TNF}$ applied, either alone or in the presence of an excess of the unlabelled TNF $\left(1,000 \mathrm{ng} \cdot \mathrm{mL}^{-1}\right)$ in $150 \mu \mathrm{L}$ PBS containing $0.5 \%$ BSA (Sigma) and $15 \mathrm{mM}$ sodium azide (PBS/BSA) according to the method of HoltmanN and
Wallach [24]. Two hours after incubation at $4{ }^{\circ} \mathrm{C}$ with constant shaking, the A549 cells were rinsed three times with PBS/BSA, detached in $\mathrm{Ca}^{2+}$ and $\mathrm{Mg}^{2+}$ free PBS containing $5 \mathrm{mM}$ EDTA, and transferred to vials to determine the radioactivities. Specific binding of TNF was calculated by subtracting the values of binding observed in the presence of an excess of the unlabelled TNF from the value of binding observed with the labelled TNF alone. The data are presented as mean \pm SD for quadruplicate samples.

To confirm the specific binding of TNF to type I TNF-R in A549 cells, an anti-type I TNF-R monoclonal antibody (H398; Bender MedSysthems, Vienna, Austria) [25] was used to block specific ${ }^{125}$ I-TNF binding to A549 cells. A549 cells were incubated with $\mathrm{H} 398\left(10 \mu \mathrm{g} \cdot \mathrm{mL}^{-1}\right)$ or nonimmune mouse immunoglobulin $\mathrm{G}(\mathrm{IgG})\left(10 \mu \mathrm{g} \cdot \mathrm{mL}^{-1}\right.$, Chemicon International Inc., Temecula, CA, USA) for $10 \mathrm{~min}$ before the addition of ${ }^{125} \mathrm{I}-\mathrm{TNF}$ at $4^{\circ} \mathrm{C}$, and specific ${ }^{125} \mathrm{I}-\mathrm{TNF}$ binding was evaluated by the method described.

\section{Shedding soluble type I TNF-R}

Excised lung tissues were incubated in serum-free RPMI 1640 medium for $24 \mathrm{~h}$. A549 cells were incubated in a serum-free RPMI 1640 medium alone or in the presence of either human recombinant TNF (1-100 $\mathrm{ng} \cdot \mathrm{mL}^{-1}$; Genzyme) or PMA (0.8-80 nM; Sigma). Soluble type I TNF-R in the culture supernatants of lung tissues and A549 cells were quantified using enzyme-linked immunoassay (Quantikine; R\&D systems, Minneapolis, MN, USA).

\section{Statistical significance}

Data on concentrations of type I soluble TNF-R in culture media were analysed by analysis of variance (ANOVA). A p-value of less than 0.05 was considered to have statistical significance.

\section{Results}

Gene expression of tumour necrosis factor receptors in human lung tissue and a pulmonary epithelial cell line

Northern blot analyses demonstrated that both whole lung tissues and A549 cells express $3.0 \mathrm{~kb}$ type I TNF-R messenger ribonucleic acid (mRNA) transcript as well as $\beta$-actin mRNA transcripts (fig. 1). However, type II TNF-R gene expression was noted only in whole lung tissue, not in A549 cells.

\section{Modulation of type I TNF-R gene expression in A549} cells

Effects of TNF and PMA on type I TNF-R gene expression in A549 cells are shown in figures 2 and 3. TNF downregulated its own receptor gene expression in a time-dependent manner. In contrast, PMA upregulated TNF-RI mRNA transcript levels. Unstimulated A549 cells did not alter TNF-R gene expression during $20 \mathrm{~h}$ (fig. 2). Control $\beta$-actin gene expression remained unchanged in the absence or the presence of TNF and PMA. 


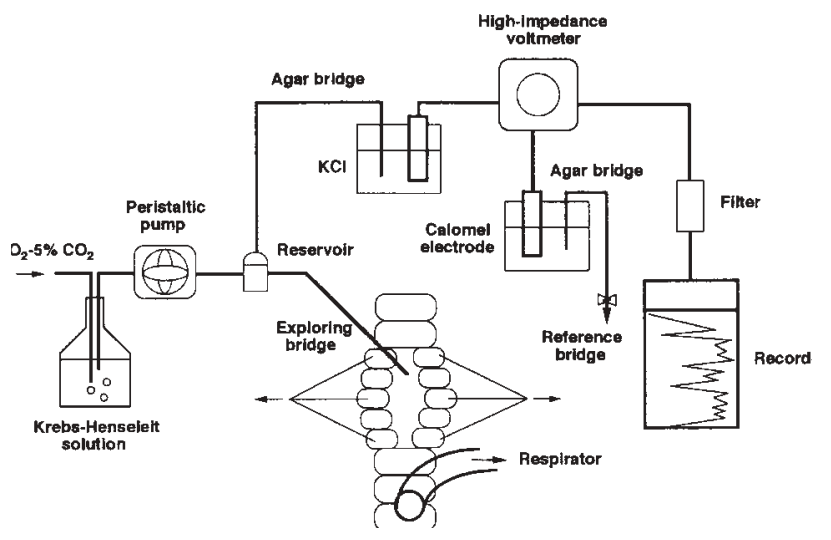

Fig. 1. - Type I and II TNF-R gene expression in whole lung tissue and A549 cells. Data shown are Northern blot analysis of RNA (12 ug each) from whole lung tissues and resting A549 cells. Nylon membranes were hybridized with a ${ }^{32} \mathrm{P}-$ labelled type I TNF-R cDNA probe (lanes 1,2 ), type II TNF-R cDNA probe (lanes 3,4 ), and $\beta$-actin probe (lanes 5,6 ). The sizes of mRNA transcripts are indicated by arrows. TNF-R: tumour necrosis factor receptor; RNA: ribonucleic acid; cDNA: complementary deoxyribonucleic acid; mRNA: messenger RNA.

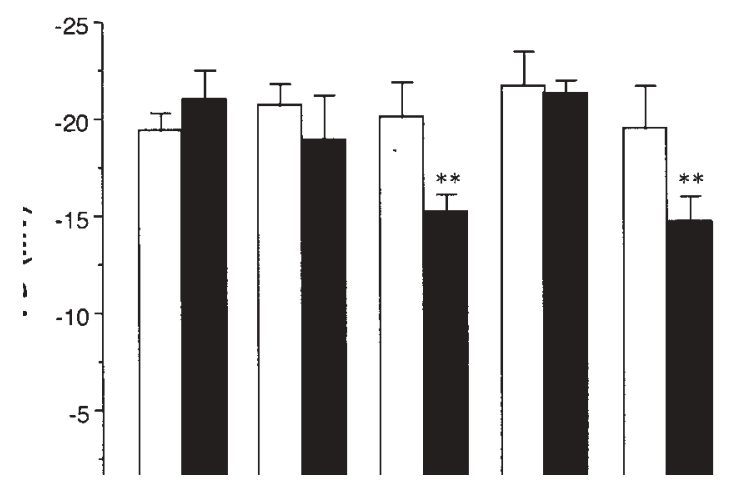

Fig. 2. - Effects of TNF on type I TNF-R gene expression in A549 cells. A549 cells were treated with or without recombinant human TNF $\left(10 \mathrm{ng} \cdot \mathrm{mL}^{-1}\right)$ for 3,6 and $20 \mathrm{~h}$, and total RNA $(12 \mu \mathrm{g})$ was extracted and subjected to Northern blot analyses. a) type I TNF-R mRNA transcripts; b) control $\beta$-actin mRNA transcripts. The autoradiograph is representative of three independent Northern blot analyses. For definitions see legend to figure 1 .

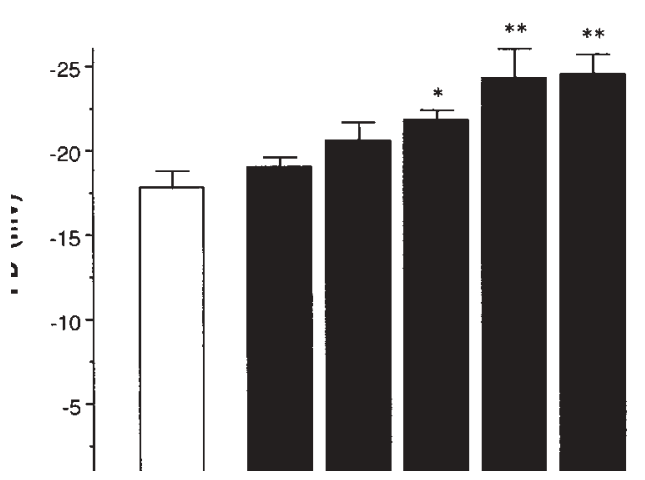

Fig. 3. - Effects of PMA on type I TNF-R gene expression in A549 cells. A549 cells were incubated in the absence or presence of $80 \mathrm{nM}$ PMA for 3, 6 and $20 \mathrm{~h}$. Total cellular RNA (12 $\mu \mathrm{g})$ extracted from A549 cells was evaluated by Northern blot analyses, and hybridized with: a) a ${ }^{32}$ P-labelled type I TNF-R cDNA probe; and b) a $\beta$-actin probe. The autoradiograph is representative of two separate experiments. PMA: phorbol myristate acetate. For further definitions see legend to figure 1 .
Table 1. - Effect of PMA and TNF on the regulation of 125/-TNF binding in A549 cells

\begin{tabular}{lcc}
\hline Treatment & $\begin{array}{c}\text { Specific } \\
\text { cpm }\end{array}$ & $\begin{array}{c}\% \text { of control } \\
\%\end{array}$ \\
\hline Rest & $1489 \pm 127$ & $100 \pm 8$ \\
PMA & $3123 \pm 210$ & $210 \pm 12$ \\
TNF & $837 \pm 239$ & $56 \pm 15$ \\
& & \\
Rest & $1399 \pm 201$ & $100 \pm 14$ \\
PMA & $3876 \pm 322$ & $282 \pm 23$ \\
TNF & $687 \pm 165$ & $49 \pm 12$ \\
\hline
\end{tabular}

Data are presented as mean \pm SD in cpm or percentage of resting levels from quadruplicate assays in two independent experiments. PMA: phorbol myristate acetate; TNF: tumour necrosis factor; cpm: counts per minute.

TNF binding to unstimulated TNF- or PMA-stimulated A549 cells

Twenty four hours after incubation with PMA, specific TNF binding to A549 cells was increased to approximately twice (210-280\%) that of the resting level (table 1). In contrast, after $24 \mathrm{~h}$ stimulation with TNF, specific TNF binding to A549 cells was decreased to half the level of resting cells. A monoclonal anti-type I TNF-R antibody, H398, blocked the binding of ${ }^{125}$ I-TNF (21.5 \pm $6.6 \%$ of control binding) although nonimmune mouse IgG failed to block the ${ }^{125} \mathrm{I}-\mathrm{TNF}$ binding to A549 cells ( $96.6 \pm 1.9 \%$ of control binding).

Soluble type I TNF-R shed from lung tissue and A549 cells

Excised lung tissues spontaneously shed type I soluble TNF-R into the culture supernatant (fig. 4a). Similar to lung tissues, A549 cells also spontaneously shed type I soluble TNF-R (fig. 4b). Importantly, both TNF and PMA accelerated the shedding of TNF-R into the culture medium in a dose-dependent fashion.

\section{Discussion}

In this study, we have demonstrated the gene expression both of type I and II TNF-R in human lung tissue. Abdolrasulnia and Shepherd [26] have reported the presence of type I and type II TNF-R proteins in human lungs, which corresponds well with the findings of the present study. Although we used a larger cDNA fragment for type II TNF-R than type I TNF-R in Northern blot analysis, the gene expression level of type II TNF-R was relatively lower than type I TNF-R in the normal lungs. However, it should be noted that the levels of gene expression do not always parallel surface expression levels or protein levels. We also noted both type I and type II TNF-R mRNA transcripts in human alveolar macrophages (data not shown). Levels of gene and surface expression of TNF-Rs in the various cell types of human lung tissue remain to be elucidated.

The pivotal element of the cellular response to TNF is the binding to its specific receptors on the plasma membrane of the target cells. The lung epithelial cell seems to be one of the most important target cells for 
a)

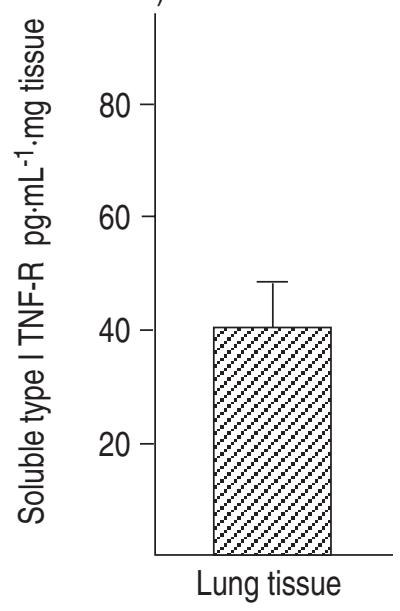

b)

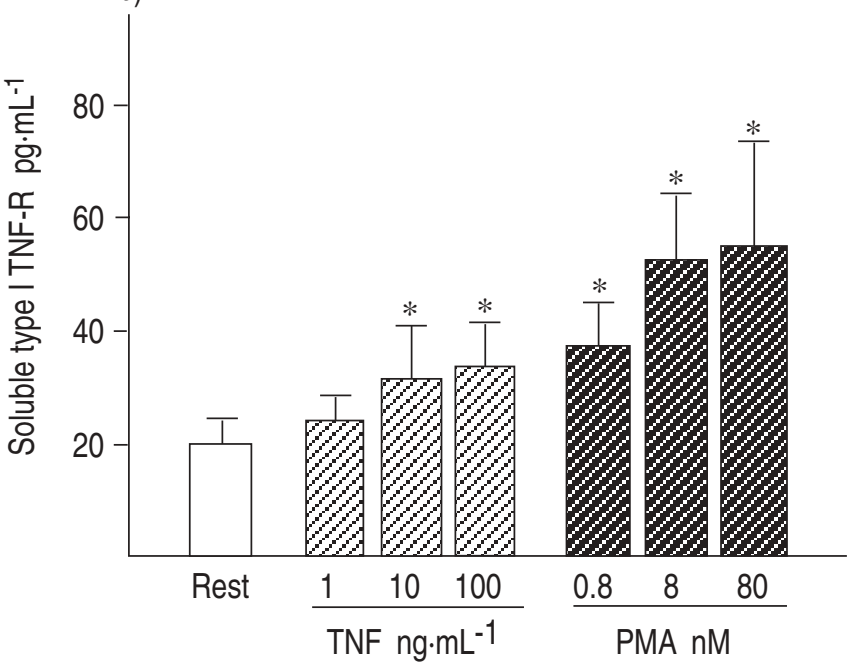

Fig. 4. - Shedding of soluble type I TNF-R into culture supernatant from whole lung tissues and A549 cells. a) Sliced lung tissues obtained by surgical resection were incubated in serum-free RPMI 1640 medium for $24 \mathrm{~h}$. Levels of soluble type I TNF-R in culture supernatants were evaluated by enzyme-lined immunoassay. b) A549 cells were cultured in the absence or the presence of TNF (1-100 ng.mL-1) or PMA (0.8-80 nM) for $24 \mathrm{~h}$. Culture supernatants were evaluated for concentrations of soluble type I TNF-R by enzyme-linked immunoassay. Data are mean \pm SD of three different experiments. Both TNF and PMA accelerated the shedding of TNF-R. *: p<0.05, compared with resting level. For definitions see legends to figures 1 and 3 .

TNF actions, such as inducing gene expression of interleukin-8 [22, 27], granulocyte/macrophage colony-stimulating factor [27], superoxide dismutase [28], and surfactant protein A [29]. We demonstrated type I but not type II TNF-R gene expression in A549 cells by Northern blot analyses. Our results, as well as the findings of other researchers [30], support the concept that type I TNF-R is the dominant receptor in epithelial cells. These observations were not consistent with those of HiguchI and AgGarwal [31], who noted type II TNF-R proteins in A549 cells; we do not know the precise reason for this discrepancy. However, there is a possibility that expression of type II TNF-R might be induced by unknown stimuli or in unknown conditions in A549 cells.

Modulation of TNF-R levels on lung epithelial cells by inflammatory mediators would imply that the response to TNF mediated by target cell receptors can be modulated by other cytokines and inflammatory mediators. Several mechanisms are known to be involved in the regulation of TNF-R surface expression. Firstly, immediately after stimulation with PMA or TNF, surface expression of TNF-R is decreased by the internalization of TNF-R [25, 31-34]. We also confirmed this in this study (data not shown). Secondly, we showed that modulations in specific TNF bindings by PMA or TNF parallel the modulation of TNF-R gene expression, where PMA upregulates and TNF downregulates type I TNF-R mRNA transcript levels in A549 cells. This evidence suggests that surface expression of TNF-R is regulated, at least in part, at the gene expression level. This type of modulation for TNF-R expression has been reported by others [30, 35-37], while our study seems to be the only report providing evidence that TNF downregulates the mRNA expression of its own receptor gene. It should be noted that this type of modulation needs several hours for protein synthesis. Finally, shedding of soluble TNF-R was reported to downregulate the surface expression of TNF-R [38, 39]. In our study, accelerated shedding of type I soluble TNF-R by TNF itself is associated with downregulation both of surface expression and gene expression of type I TNF-R. These results are consistent with the concept of LANTZ et al. [38], who suggested increased production of soluble TNF-Rs from HL-60 under conditions which favour downregulation of the TNF-R. However, this is not always true, as we noted that PMA increased not only shedding of soluble type I TNF-R but also the gene expression and surface expression of receptor in A549 cells.

In summary, two types of tumour necrosis factor receptor gene were expressed in lung tissue; however, A549 cells as a model of type II alveolar epithelial cells express only type I tumour necrosis factor receptor gene. In this cell line, type I tumour necrosis factor receptor gene and surface expression, and shedding of the soluble receptor are differentially regulated by tumour necrosis factor and phorbol ester. Our study suggests the importance of expression and modulation of tumour necrosis factor receptor gene in normal and diseased lungs in terms of the various actions of tumour necrosis factor action in vivo.

\section{References}

1. Sherry B, Cerami A. Cachectin/tumor necrosis factor exerts endocrine, paracrine, and autocrine control of inflammatory responses. J Cell Biol 1988; 107: 1269-1277.

2. Vilcek J, Lee TH. Tumor necrosis factor: new insights into the molecular mechanisms of its multiple actions. J Biol Chem 1991; 266: 7313-7316.

3. Kelley J. Cytokines of the lung. Am Rev Respir Dis 1990; 141: 765-788.

4. Piguet PF, Collart MA, Grau GE, Kapanci Y, Vassalli $\mathrm{P}$. Tumor necrosis factor/cachectin plays a key role in bleomycin-induced pneumopathy and fibrosis. $J$ Exp Med 1989; 170: 655-663.

5. Piguet PF, Colart MA, Grau GE, Sappino A-P, Vassalli P. Requirement of tumor necrosis factor for development of silica-induced pulmonary fibrosis. Nature 1990; 344: 245-247.

6. Millar AB, Singer M, Meager A, Foley NM, Johnson NM, Rook GAW. Tumor necrosis factor in bronchopulmonary 
secretions of patients with adult respiratory distress syndrome. Lancet 1989; ii: 712-714.

7. Hohmann HP, Remy R, Brockhaus M, van Loon APGM. Two different cell types have different major receptors for human tumor necrosis factor (TNF-alpha). J Biol Chem 1989; 264: 14927-14934.

8. Engelmann H, Novick D, Wallach D. Two tumor necrosis factor-binding proteins purified from human urine: evidence for immunological cross-reactivity with cell surface tumor necrosis factor receptors. J Biol Chem 1990; 265: 1531-1536.

9. Brockhaus M, Schoenfeld HJ, Schlaeger EJ, Hunziker W, Lesslauer W, Loetscher H. Identification of two types of tumor necrosis factor receptors on human cell lines by monoclonal antibodies. Proc Natl Acad Sci USA 1990; 87: 3127-3131.

10. Loetscher H, Pan Y-CE, Lahm H-W, et al. Molecular cloning and expression of the human $55 \mathrm{kD}$ tumor necrosis factor receptor. Cell 1990; 61: 351-359.

11. Schall TJ, Lewis M, Koller KJ, et al. Molecular cloning and expression of a receptor for human tumor necrosis factor. Cell 1990; 61: 361-370.

12. Nophar Y, Kemper O, Brakebusch C, et al. Soluble forms of tumor necrosis factor receptors (TNF-Rs): the cDNA for the type I TNF-R, cloned using amino acid sequence data of its soluble form of the receptor. $E M B O$ $J$ 1990; 9: 3269-3278.

13. Smith CA, Davis T, Anderson D, et al. A receptor for tumor necrosis factor defines an unusual family of cellular and viral proteins. Science 1990; 25: 1019-1023.

14. Heller RA, Song K, Onasch MA, Fischer WW, Change D. Complementary DNA cloning of a receptor for tumor necrosis factor and demonstration of a shed form of the receptor. Proc Natl Acad Sci USA 1990; 87: 6151-6155.

15. Tartaglia LA, Weber RF, Figari IS, Reynolds C, Palladino MA Jr, Goeddel DV. The two different receptors for tumor necrosis factor mediate distinct cellular responses. Proc Natl Acad Sci USA 1991; 88: 9292-9296.

16. Hohmann HP, Brockhaus M, Baeuerle PA, Remy R, Kolbeck R, van Loon APGM. Expression of the two types $\alpha$ and $\beta$ tumor necrosis factor (TNF) is independently regulated, and both receptors mediate activation of the transcription factor NF-kB. J Biol Chem 1990; 265: 22409-22417.

17. Kalthoff H, Roeder C, Brockhaus M, Thiele HG, Schmiegel W. Tumor necrosis factor upregulates the expression of p75 but not p55 TNF receptors, and both mediate, independently of each other, upregulation of transforming growth factor-alpha and epidermal growth factor receptor mRNA. J Biol Chem 1993; 268: 2762-2766.

18. Sanger F, Nicklen S, Coulsonn AR. DNA sequencing with chain-terminating. Proc Natl Acad Sci USA 1977; 74: 5463-5467.

19. Gunning P, Ponte P, Okayama H, Enhel J, Blau H, Kedes L. Isolation and characterization of full-length cDNA clones for human $\alpha-, \beta$-, $\gamma$-actin mRNAs; skeletal but not cytoplasmic actins have an amino-terminal cysteine that is subsequently removed. Mol Cell Biol 1983; 3: 787-795.

20. Chomczynski P, Sacchi N. Single-step method of RNA isolation by acid guanidium thiocyanate-phenol-chloroform extraction. Anal Biochem 1987; 162: 156-159.

21. Ausubel FM, Brent R, Kingston RE, Moore DD, Seidman JG, Smith JA, Struhl K, eds. Analysis of RNA by Northern hybridization. In: Current Protocols in Molecular Biology. New York, John Wiley, 1987; pp. 4.9.1.-4.9.8.

22. Nakamura H, Yoshimura K, Jaffe HA, Crystal RG.
Inter-leukin-8 gene expression in human bronchial epithelial cells. J Biol Chem 1991; 266: 19611-19617.

23. Feinberg AP, Vogelstein B. A technique for radiolabeling DNA restriction endonuclease fragments to high specific activity. Anal Biochem 1983; 132: 6-13.

24. Holtmann H, Wallach D. Downregulation of the receptors for tumor necrosis factor by interleukin-1 and 43-phorbol-12-myristate-13-acetate. J Immunol 1987; 139: 1161-1167.

25. Kruppa G, Thoma B, Machleidt T, Wiegmann K, Kronke M. Inhibition of tumor necrosis factor (TNF)-mediated NF- $\kappa \mathrm{B}$ activation by selective blockade of the human 55 $\mathrm{kDa}$ TNF receptor. J Immunol 1992; 148: 3152-3157.

26. Abdolrasulnia R, Shepherd VL. Purification of type I and type 11 tumor necrosis factor receptors from human lung tissue. Am J Respir Cell Mol Biol 1992; 7: 42-48.

27. Bedard M, McClure CD, Schiller NL, Francoeur C, Cantin A, Denis M. Release of interleukin-8, interleukin-6 and colony-stimulating factors by upper airway epithelial cells; implications for cystic fibrosis. Am $J$ Respir Cell Mol Biol 1993; 9: 455-462.

28. Visner GA, Dougall WC, Wilson JM, Burr IA, Nick HS. Regulation of manganese superoxide dismutase by lipopolysaccharide, interleukin-1 and tumor necrosis factor. J Biol Chem 1990; 265: 2856-2864.

29. Wispe JR, Clark JC, Warner BB, et al. Tumor necrosis factor-alpha inhibits expression of pulmonary surfactant protein. J Clin Invest 1990; 86: 1954-1960.

30. Trfezer U, Brockhaus M, Lotscher $\mathrm{H}$, et al. The $55 \mathrm{kDa}$ tumor necrosis factor receptor on human keratinocytes is regulated by tumor necrosis factor-alpha and by ultraviolet B radiation. J Clin Invest 1993; 92: 462-470.

31. Higuchi M, Aggarwal BB. Modulation of two forms of tumor necrosis factor receptors and their response by soluble receptors and their monoclonal antibodies. J Biol Chem 1991; 267: 20892-20899.

32. Tsujimoto M, Oku N. Regulation of TNF receptors. In: Aggarwal BB, Vilcek J, eds. Tumor Necrosis Factors: Structure, Function and Mechanism of Action. New York, Marcel Dekker, 1991; pp. 149-160.

33. Wallach D, Holtmann H, Engelmann H, Nophar Y. Sensitization and desensitization to lethal effects of tumor necrosis factor and IL-1. J Immunol 1988; 140: 2994-2999.

34. Tsujimoto M, Vileck J. Tumor necrosis factor-induced downregulation of its receptors in Hela cells. J Biochem 1987; 102: 1571-1577.

35. Winzen R, Wallach D, Engelmann H, et al. Selective decrease in cell surface expression and mRNA level of the $55 \mathrm{kDa}$ tumor necrosis factor receptor during differentiation of HL-60 cells into macrophage-like but not granulocyte cells. J Immunol 1993; 148: 3454-3460.

36. Kalthoff H, Roeder C, Brockhaus M, Thiele H-G, Schmiegel W. Tumor necrosis factor (TNF) upregulates the expression of p75 but not p55 TNF receptors, and both receptors mediate, independently of each other, upregulation of transforming growth factor- $\alpha$ and epidermal growth factor receptor mRNA. J Biol Chem 1993; 268: 2762-2766.

37. Winzen R, Wallach D, Kemper O, Resch K, Holtmann $\mathrm{H}$. Selective upregulation of the $75 \mathrm{kDa}$ tumor necrosis factor (TNF) receptor and its mRNA by TNF and IL-1. J Immunol 1993; 150: 4346-4353.

38. Lantz M, Gullberg U, Nilsson E, Olsson I. Characterization in vitro of a human tumor necrosis factor-binding protein. J Clin Invest 1990; 86: 1396-1402.

39. Higuchi M, Aggarwal BB. Okadaic acid induces downmodulation and shedding of tumor necrosis factor receptors. J Biol Chem 1993; 268: 5624-5631. 